\title{
Efficacy and Application Strategies for Propiconazole as a New Postharvest Fungicide for Managing Sour Rot and Green Mold of Citrus Fruit
}

\author{
A. H. McKay, H. Förster, and J. E. Adaskaveg, Department of Plant Pathology and Microbiology, University of California, Riverside \\ 92521
}

\begin{abstract}
McKay, A. H., Förster, H., and Adaskaveg, J. E. 2012. Efficacy and application strategies for propiconazole as a new postharvest fungicide for managing sour rot and green mold of citrus fruit. Plant Dis. 96:235-242.

Few postharvest treatments are available for managing sour rot of citrus caused by Galactomyces citri-aurantii and they are generally not very effective. The demethylation-inhibiting (DMI) triazole fungicides propiconazole and cyproconazole were found to be highly effective and more efficacious than other DMIs evaluated, such as metconazole and tebuconazole, in reducing postharvest sour rot of citrus. Additional studies were conducted with propiconazole as a postharvest treatment because it has favorable toxicological characteristics for food crop registration in the United States and the registrant supports a worldwide registration. Regression and covariance analyses were performed to determine optimal time of application after inoculation and fungicide rate. In laboratory studies, decay incidence increased when propiconazole applications were delayed from 8 to $24 \mathrm{~h}$ (lemon) or 18 to 42 $\mathrm{h}$ (grapefruit) after inoculation. Effective rates of the fungicide were 64 to $512 \mu \mathrm{g} / \mathrm{ml}$ and were dependent on inoculum concentration of the sour rot pathogen and on the type of citrus fruit. Propiconazole was found to be compatible with sodium hypochlorite at $100 \mu \mathrm{g} / \mathrm{ml}$ and 1 to

lemon. The addition of hydrogen peroxide/peroxyacetic acid at 80 $\mu \mathrm{g} / \mathrm{ml}$ slightly decreased the effectiveness of propiconazole. Heated $\left(48^{\circ} \mathrm{C}\right)$ solutions of propiconazole did not significantly improve the efficacy compared with solutions at $22^{\circ} \mathrm{C}$. In experimental packing-line studies, aqueous in-line drenches applied alone or followed by applications of the fungicide in storage or packing fruit coatings were highly effective, reducing sour rot to between 0 and $1.2 \%$ compared with $83.8 \%$ decay incidence in the control when treatments were made up to $16 \mathrm{~h}$ after inoculation. When the fungicide was applied in either fruit coating, decay was only reduced to 49.1 to $57.1 \%$ incidence. Tank mixtures of propiconazole with the citrus postharvest fungicides fludioxonil and azoxystrobin were highly effective in reducing green mold caused by isolates of Penicillium digitatum sensitive or moderately resistant to imazalil and sour rot. Propiconazole will be an important postharvest fungicide for managing sour rot of citrus and potentially can be integrated into current management practices to reduce postharvest crop losses caused by DMI-sensitive isolates of $P$. digitatum.
\end{abstract} $3 \%$ sodium bicarbonate without loss of efficacy for decay control on
Sour rot of citrus fruit, caused by the soilborne fungal pathogen Galactomyces citri-aurantii E.E. Butler (anamorph: Geotrichum citri-aurantii (Ferraris) E.E. Butler), is an economically important postharvest disease affecting California's estimated $\$ 1.7$ billion annual (2008 to 2009) citrus crop (3). Sour rot ranks second in postharvest decay losses after decays caused by Penicillium spp. Of the latter, Penicillium digitatum (Pers.) Sacc. is the most important postharvest pathogen of citrus produced in semiarid climates like California (20). Conidia are disseminated by water splash from rain or irrigation sprinklers, by airborne soil dust particles, or by insects and other animals to the surface of fruit, where they can cause infections at sites of injury $(4,7,16,17)$. The pathogen infects through fruit injuries that mainly occur during harvest and subsequent postharvest handling $(7,17,20)$. In storage, the disease may result in complete collapse and liquefaction of infected fruit. Juices dripping from infected fruit can readily spread the pathogen to healthy fruit (20). In California, sour rot is particularly problematic on lemon (Citrus limon (L.) N.L. Burm.) grown in the coastal regions, as well as on mandarin fruit ( $C$. reticulata Blanco) that are often stored for extended periods at relatively high temperatures of 12 to $14^{\circ} \mathrm{C}$ to obtain marketable rind color $(17,35)$. Sour rot can

Corresponding author: J. E. Adaskaveg, E-mail: jim.adaskaveg@ucr.edu

Current address of A. H. McKay: The New Zealand Institute for Plant \& Food Research Ltd., Mount Albert Research Centre, Private Bag 92169, Auckland 1142, New Zealand.

Accepted for publication 4 September 2011.

http://dx.doi.org/10.1094/PDIS-06-11-0525

(C) 2012 The American Phytopathological Society also cause high postharvest losses on grapefruit ( $C$. paradisi Macf.) and orange (C. sinensis L.) (9). Overall, outbreaks of the disease are sporadic, with highest incidences on fruit that are harvested during prolonged wet conditions $(4,17)$.

Several fungicides are currently registered in the United States for postharvest management of Penicillium decays, including the sterol demethylation-inhibiting (DMI) imidazole imazalil, the methyl benzimidazole carbamate thiabendazole, as well as three recently introduced compounds: the quinone outside inhibitor (QoI) azoxystrobin, the phenylpyrrole fludioxonil, and the anilinopyrimidine pyrimethanil. None of these, however, is effective against sour rot $(11,30)$. Sodium ortho-phenylphenate (SOPP), a broad-spectrum phenolic-based fungicide, has some activity against sour rot and is registered for postharvest application to citrus but concentrations required to effectively manage sour rot can result in phytotoxicity (7). Additionally, use of SOPP by the citrus industry has been in decline over recent years due to disposal and human safety concerns (34). Guazatine, a guanidine fungicide available in other parts of the world, has very good efficacy against sour rot $(28,36)$. This fungicide, however, will not be registered in the United States because it contains multiple active ingredients and there is no method to analyze fungicide residues on fruit.

The DMI-triazole propiconazole is a new postharvest fungicide in the United States that is planned for registration on citrus, stone fruit, and other fruit crops such as tomato. It is highly effective against several important decays, including those caused by species of Penicillium, Rhizopus, and Monilinia. Most importantly, however, it is effective against the sour rot pathogens Galactomyces geotrichum (E.E. Butler \& L.J. Petersen) Redhead \& Malloch (anamorph: Geotrichum candidum Link) that affects stone fruit, tomato, and other crops (10) and Galactomyces citri-aurantii (24). In comparative evaluations of several DMI-triazole fungicides against growth of G. citri-aurantii in vitro, propiconazole, cypro- 
conazole, and metconazole were the most effective compounds evaluated (25).

The goal of this study was to evaluate the efficacy of propiconazole against citrus sour rot and also green mold. We addressed several aspects in optimizing efficacy that will be valuable for the upcoming commercial use of the fungicide. Usage rates have been determined for stone fruit and tomato $(1,10)$ but need to be established for citrus fruit. This is partly due to a lower toxicity of propiconazole against mycelial growth of $G$. citri-aurantii compared with G. geotrichum (24) but also because different types of crops and handling systems are involved. Proper timing of postharvest applications is another critical aspect of postharvest treatments, and different fungicides have been shown to differ in postinfection characteristics. For example, imazalil and pyrimethanil provided almost complete decay control when applied 9 to $21 \mathrm{~h}$ after inoculation for green mold control of lemon fruit, whereas efficacy of azoxystrobin and fludioxonil was significantly reduced when applied later than $12 \mathrm{~h}$ after inoculation (22).

Postharvest fungicides are commonly applied in combination with a fruit coating to prevent water loss from fruit during storage (storage coatings) or to improve the appearance of fruit prior to marketing (packing coatings). When directly mixed with fruit coatings, fungicide efficacy can be affected, as shown previously for fungicides used to control citrus green mold (22). This interaction also needs to be investigated for propiconazole. Other strategies that have been employed to maximize postharvest treatment efficacy for citrus fruit are the use of heated $\left(41\right.$ to $\left.50^{\circ} \mathrm{C}\right)$ fungicide solutions, as shown for imazalil and thiabendazole (33). The addition of sodium bicarbonate (SBC) or potassium sorbate improved the performance of citrus postharvest fungicides for management of green mold decay (30-32).

Due to their high effectiveness, recirculating in-line drench applications of fungicides are increasingly being used commercially for citrus fruit in California. With this practice, the build-up of microbial populations in the treatment solutions should be prevented by using a sanitizer to avoid contamination of healthy fruit and to minimize selection of fungicide-resistant propagules (23). Some fungicides, however, are not stable under these oxidizing conditions. For example, among the citrus postharvest fungicides, fludioxonil and thiabendazole are stable in solutions of chlorine or SBC-chlorine, whereas imazalil and pyrimethanil are not (23). In packinghouses, sanitizing treatments are also used to inactivate inoculum on fruit surfaces and to clean equipment (20). Because the use of chlorine is currently subjected to tighter restrictions due to health safety and environmental concerns, new sanitizers such as hydrogen peroxide/peroxyacetic acid (HPPA) are being developed for use by the food industry. Both ingredients of HPPA have antimicrobial activity and leave no toxic residuals. Unlike chlorine, however, peroxyacetic acid remains effective in the presence of organic material (6). Thus, the compatibility of propiconazole with SBC and sanitizers needs to be evaluated.

Thus, the specific objectives of this study were to evaluate (i) the efficacy of selected DMI-triazole fungicides in reducing sour rot of citrus; (ii) the efficacy of propiconazole as affected by rate and application timing after inoculation; (iii) interactions of propiconazole with the sanitizing agents sodium hypochlorite and HPPA, with SBC, as well as with citrus fruit coatings; and (iv) the effect of heated propiconazole solutions on decay control. Additionally, we evaluated the effectiveness of propiconazole applied by itself or in a mixture with azoxystrobin and fludioxonil against decay caused by isolates of $P$. digitatum sensitive or resistant to imazalil.

\section{Materials and Methods}

Fungal isolates and inoculation of fruit. Single-spore isolates of G. citri-aurantii (isolate Gca-67) and P. digitatum were obtained from infected lemon fruit in citrus packinghouses in California. Two isolates of $P$. digitatum were used: an isolate sensitive to imazalil and thiabendazole (isolate $\mathrm{Pd} ; 50 \%$ effective concentration $\left[\mathrm{EC}_{50}\right]$ values for mycelial growth 0.05 and $0.08 \mu \mathrm{g} / \mathrm{ml}$, respectively) and an isolate less sensitive to the two fungicides (isolate
3129; $\mathrm{EC}_{50}$ value for mycelial growth $0.32 \mu \mathrm{g} / \mathrm{ml}$ and $>7.82 \mu \mathrm{g} / \mathrm{ml}$, respectively). For inoculum production, isolates were grown for 5 to 14 days at $25^{\circ} \mathrm{C}$ on potato dextrose agar (PDA; Difco Laboratories, Detroit). Isolates were maintained as mycelial plugs in sterile water at $4^{\circ} \mathrm{C}$ for up to 1 year.

'Eureka' and 'Lisbon' lemon fruit as well as 'Oroblanco' grapefruit used in the studies were not treated with any pre- or postharvest fungicide and were obtained from research orchards at the University of California, Riverside, and the University of California, Kearney Agricultural Center, Parlier, or from citrus packinghouses. Fruit arriving from the orchard at the packinghouses were collected following a dump tank treatment with sodium hypochlorite at $100 \mu \mathrm{g} / \mathrm{ml}$ and a water rinse. Fruit from the research orchards were hand-washed with sodium hypochlorite at $100 \mu \mathrm{g} / \mathrm{ml}$ and rinsed with tap water. Fruit were placed in plastic fruit trays in cardboard fruit boxes and allowed to air dry at ambient temperature $\left(20\right.$ to $\left.25^{\circ} \mathrm{C}\right)$ before inoculation. Fruit either were inoculated the day of harvest or stored at $10^{\circ} \mathrm{C}$ for up to 7 days before use.

For inoculation with $G$. citri-aurantii, conidial suspensions $(5 \times$ $10^{5}$ or $1 \times 10^{7}$ conidia $/ \mathrm{ml}$ ) were prepared in sterile water or in autoclaved lemon juice with or without the addition of cycloheximide at $2 \mu \mathrm{g} / \mathrm{ml}$ (Sigma-Aldrich, St. Louis) (19). For P. digitatum, conidial inoculum $\left(1 \times 10^{6}\right.$ conidia/ml $)$ was prepared in sterile water with the addition of $0.01 \%$ ( $\mathrm{vol} / \mathrm{vol}$ ) Tween 20 (Sigma-Aldrich). For each treatment and for each of the four replications used in each experiment, 12 grapefruit or 24 lemon fruit were used. When two inoculum concentrations were used in experiments with $G$. citri-aurantii, they were done at different sites on the same fruit approximately $20 \mathrm{~mm}$ from the stem and blossom ends of the fruit. For $P$. digitatum, fruit was inoculated at a single site. Conidial suspensions of each fungus $(20-\mu 1$ droplets) were pipetted onto the fruit, and the flavedo (exocarp) and albedo (mesocarp) beneath each droplet were then wounded using a stainless steel probe that created a 1-by-2-mm injury that did not penetrate beyond the albedo. Trays with fruit inoculated with $G$. citri-aurantii were placed into plastic storage boxes (volume approximately 28 liters; Sterilite, Townsend, MA) and $200 \mathrm{ml}$ of water was added to the bottom of each box to provide high relative humidity (fruit were not in contact with the water). For $P$. digitatum, fruit trays were placed into cardboard fruit boxes that were covered with plastic bags.

All fruit were incubated for selected times at $20^{\circ} \mathrm{C}$ before treatment. After treatment, fruit were incubated for 6 days at the same temperature. Incidence of decay was calculated based on the number of infected fruit of the total number of fruit used. The specific studies with inoculated fruit described below were all conducted two or three times.

Fungicides and sanitation agents. Fungicides used were formulated products of the DMI-triazoles cyproconazole (Alto 100SL; Syngenta Crop Protection, Greensboro, NC), metconazole (Quash 50WDG; Valent USA, Walnut Creek, CA), propiconazole (Mentor 45WP; Syngenta Crop Protection), and tebuconazole (Elite 45WP; Bayer Crop Science, Research Triangle Park, NC), as well as a premixture of the phenylpyrrole fludioxonil and the QoI azoxystrobin (Graduate A+ SL; Syngenta Crop Protection). Industrial-grade sodium bicarbonate (FMC Wyoming Corp., Green River, WY) and the sanitizers sodium hypochlorite (household bleach, containing approximately $5.25 \% \mathrm{NaOCl}$ ) and HPPA (Perasan C5, 22.5\% hydrogen peroxide; EnviroTech Chemical Services, Inc., Modesto, CA) were used alone or in combination with fungicides. For treatment, fungicides and sanitizers were diluted to the desired concentrations with distilled water in laboratory studies or with tap water in experimental packing-line studies.

Efficacy of selected DMI-triazole fungicides in reducing postharvest sour rot of lemon. Fruit were wound inoculated with G. citri-aurantii $\left(1 \times 10^{7}\right.$ conidia/ml, prepared in sterile water with the addition of cycloheximide at $2 \mu \mathrm{g} / \mathrm{ml}$ ). At selected times after inoculation (see below), fungicide treatments at $256 \mu \mathrm{g} / \mathrm{ml}$ were applied to run-off using a hand-operated atomizer (Model 15-RD; DeVilbiss Health Care, Somerset, PA). Control fruit were sprayed with water. 
Effect of treatment time after inoculation and treatment rate on the efficacy of propiconazole in managing sour rot of lemon and grapefruit. For evaluation of treatment timings after inoculation, fruit were wound inoculated $\left(5 \times 10^{5}\right.$ conidia $/ \mathrm{ml}$, prepared in autoclaved lemon juice and cycloheximide added at $2 \mu \mathrm{g} / \mathrm{ml}$ for lemon; $1 \times 10^{7}$ conidia/ml, prepared in autoclaved lemon juice for grapefruit) with $G$. citri-aurantii. Lemon fruit were incubated for $12,16,20$, or $24 \mathrm{~h}$ and grapefruit were incubated for 18,30 , or 42 $\mathrm{h}$ before treatment. Treatments were applied by dipping fruit for 15 $\mathrm{s}$ in aqueous propiconazole solutions at $256 \mu \mathrm{g} / \mathrm{ml}$ (lemon and grapefruit) or $384 \mu \mathrm{g} / \mathrm{ml}$ (lemon only). Control fruit were dipped in water.

For evaluation of treatment rates, lemon and grapefruit were inoculated with G. citri-aurantii using $1 \times 10^{7}$ conidia/ml (prepared in autoclaved lemon juice) or $5 \times 10^{5}$ conidia/ml (prepared in autoclaved lemon juice with the addition of cycloheximide at $2 \mu \mathrm{g} / \mathrm{ml}$; lemon only). Treatments were applied by dipping for $15 \mathrm{~s}$ in aqueous propiconazole solutions at $12 \mathrm{~h}$ (lemon) or $18 \mathrm{~h}$ (grapefruit) after inoculation. Concentrations were 64, 128, 256, 384, and 516 $\mu \mathrm{g} / \mathrm{ml}$ for lemon and $32,64,128$, and $256 \mu \mathrm{g} / \mathrm{ml}$ for grapefruit. Control fruit were dipped in water.

Effect of sanitizing treatments and SBC on the efficacy of propiconazole in reducing sour rot of lemon. In experiments with selected additives to the propiconazole treatments, lemon fruit were inoculated with $1 \times 10^{7}$ conidia/ml (prepared in autoclaved lemon juice). Aqueous treatment solutions of propiconazole (256 or $384 \mu \mathrm{g} / \mathrm{ml}$ ) were prepared without or with the addition of sodium hypochlorite (free chlorine at $100 \mu \mathrm{g} / \mathrm{ml}$ ), HPPA (hydrogen peroxide at $80 \mu \mathrm{g} / \mathrm{ml})$, or SBC (1\% [wt/vol] or 3\% [wt/vol]). Dip treatments for $15 \mathrm{~s}$ were done 14 or $16 \mathrm{~h}$ after inoculation. Control fruit were dipped in water.

Laboratory and experimental packing-line studies on the efficacy of propiconazole using different application strategies. Comparisons of application methods, application of heated and nonheated solutions, as well as applications in combination with fruit coatings or other citrus postharvest fungicides were done. In a laboratory study, lemon fruit were inoculated with $G$. citri-aurantii $\left(1 \times 10^{7}\right.$ conidia/ml, prepared in autoclaved lemon juice $)$ and incubated for $14 \mathrm{~h}$ before treatment. Fruit were dip treated for $15 \mathrm{~s}$ or sprayed with propiconazole $(256 \mu \mathrm{g} / \mathrm{ml})$ to run-off as described above. Aqueous dip treatments were done either at ambient temperature $\left(22^{\circ} \mathrm{C}\right.$ ) or heated to $48^{\circ} \mathrm{C}$ (mean temperature) and the solution was reheated for each of the replications. Control fruit were dipped in water at ambient temperature or in water heated to $48^{\circ} \mathrm{C}$.

In an experimental packing-line study on the compatibility of propiconazole with storage and packing fruit coatings, lemon fruit were inoculated with $G$. citri-aurantii $\left(1 \times 10^{7}\right.$ conidia/ml, prepared in autoclaved lemon juice) and fruit were treated after 14 to $16 \mathrm{~h}$ on an experimental packing line at the University of California, Kearney Agricultural Center, Parlier. This packing line is equipped to treat fruit using high- and low-volume application methods over moving roller beds with a treatment area $90 \mathrm{~cm}$ wide by $120 \mathrm{~cm}$ long. Propiconazole was applied as high-volume, aqueous in-line drenches at $250 \mu \mathrm{g} / \mathrm{ml}$ or as concentrate in low-volume spray applications at $2,000 \mu \mathrm{g} / \mathrm{ml}$ in diluted storage fruit coating (Decco Lustr 202; Decco US Post-Harvest, Inc., Monrovia, CA; 1 part fruit coating diluted with 14 parts water) or undiluted packing fruit coating (Decco Pearl Lustr; Decco US Post-Harvest, Inc.). In-line drenches were applied to fruit by pumping a fungicide solution from a 70-liter reservoir to a perforated steel distribution pan (91-by-91$\mathrm{cm}$ area with 1275 - $\mathrm{mm}$ holes evenly distributed) over a moving roller bed. Treatment volumes for propiconazole were equivalent to 33 liters per $10,000 \mathrm{~kg}$ of fruit. Drench treatments were followed by a low-volume spray with diluted storage fruit coating. Low-volume sprays were done with a controlled droplet applicator (Decco US Post-Harvest, Inc.) that was positioned in the center of the treatment area and approximately $20 \mathrm{~cm}$ above the roller bed. Treatment volumes for these spray applications were adjusted to 8.3 liters per $10,000 \mathrm{~kg}$ of fruit by regulating fruit coating output volumes and speed of fruit movement through the treatment area. Treatment times were generally between 12 and $15 \mathrm{~s}$. Propiconazole was also applied in two-step applications, where the aqueous drench application $(250 \mu \mathrm{g} / \mathrm{ml})$ was followed by a low-volume spray of propiconazole $(500 \mu \mathrm{g} / \mathrm{ml})$ in diluted storage or nondiluted packing fruit coating. Control fruit were treated only with water. Between treatments, fungicide reservoirs and tubing as well as treatment beds were cleaned with a commercial alkaline detergent (PacFoam Plus; Pace International, Seattle) and then thoroughly rinsed with water.

In another study to evaluate the efficacy of propiconazole applied by itself or in mixtures with azoxystrobin/fludioxonil, lemon fruit were inoculated with isolates of $P$. digitatum $\left(10^{6}\right.$ conidia $\left./ \mathrm{ml}\right)$ either sensitive or less sensitive to imazalil or with $G$. citri-aurantii $(5 \times$ $10^{5}$ conidia/ml, prepared in autoclaved lemon juice with cycloheximide at $2 \mu \mathrm{g} / \mathrm{ml})$. Fungicide treatments were done after 12 or $16 \mathrm{~h}$ (except for the less sensitive isolate of $P$. digitatum that was only evaluated at $12 \mathrm{~h}$ ) using in-line drenches followed by a lowvolume spray application with diluted storage fruit coating, as described above. Propiconazole was used at $256 \mu \mathrm{g} / \mathrm{ml}$ when applied by itself or at $516 \mu \mathrm{g} / \mathrm{ml}$ when applied together with azoxystrobin/fludioxonil. Azoxystrobin/fludioxonil was used as the commercial premixture Graduate A+ with each fungicide at $300 \mu \mathrm{g} / \mathrm{ml}$.

Statistical analysis of data. Data for decay incidence were arcsine transformed for studies on the efficacy of DMI fungicides and the effect of sanitizers, SBC, fruit coatings, or temperature on the efficacy of propiconazole. Bartlett's test for homogeneity of variances was performed for repeated experiments. In each study, variances were homogeneous $(P<0.05)$ and, thus, combined data sets were analyzed using a balanced one-way treatment structure in a randomized complete block design. Transformed values were analyzed using general linear model or analysis of variance and least significant difference mean separation procedures of SAS (version 9.2; SAS Institute, Cary, NC).

Regression analyses were used to evaluate timing of application after inoculation and rate effects of propiconazole on transformed mean incidence of decay using SAS. Decay incidence was first normalized for each experiment by dividing the incidence value of treatment rates and timings by the decay incidence of the nontreated control. Standard errors were calculated as the square root of the variance of the experimental means. An analysis of covariance was done for comparing slopes and adjusted means of multiple regression lines. For this, the following strategy was used: (i) test the hypothesis that all slopes are equal to zero $\left(H_{0}: \beta_{1}=\beta_{2}\right.$ $=\beta_{3}=\beta_{4}=0$ versus $H_{\mathrm{a}}$ : [not $\left.H_{0}\right]$ ); (ii) determine whether a common slope model will adequately describe the data and test the hypothesis that the slope is equal to zero $\left(H_{0}: \beta_{1}=\beta_{2}=\beta_{3}=\beta_{4}=0\right.$ versus $H_{\mathrm{a}}$ : [not $\left.H_{0}\right]$ ); and (iii) fit a common slope model and determine if linear, quadratic, or cubic estimates best describe the data. Additionally, regression lines with common slopes were compared at the midpoint using adjusted means (least squares means [LSMeans]) of the regression line using mixed model procedures of SAS.

\section{Results}

Efficacy of selected DMI-triazole fungicides in reducing postharvest sour rot of lemon. In a comparative laboratory study using inoculated lemon fruit, the incidence of sour rot was significantly $(P<0.05)$ reduced from the control using all four compounds applied at $256 \mu \mathrm{g} / \mathrm{ml}$ (Fig. 1). Treatments of cyproconazole and propiconazole applied $14 \mathrm{~h}$ after inoculation were significantly more effective than those with metconazole or tebuconazole. The incidence of decay after six days of incubation at $20^{\circ} \mathrm{C}$ was $93.7 \%$ for the water-treated control and 11.4, 13.0, 31.3, and 35.1\% for propiconazole, cyproconazole, metconazole, and tebuconazole, respectively.

Effect of treatment time after inoculation and treatment rate on the efficacy of propiconazole in managing sour rot of lemon and grapefruit. Decay incidence increased when applications were delayed after inoculation. In the regression analysis, the models for both rates of propiconazole tested on lemon (256 and 384 
$\mu \mathrm{g} / \mathrm{ml})$ as well as the $256-\mu \mathrm{g} / \mathrm{ml}$ rate tested on grapefruit were significant $(P<0.01$ for all regression models) and coefficients of determination of the regression lines were 0.86 to 0.98 . The slopes of the regressions of transformed decay incidence on application time after inoculation were positive (Fig. 2A and B). In the analyses of covariance, slopes for the regression lines were not significantly different $(P=0.74)$ for the two application rates used on lemon and the model estimates indicated a strong linear relationship between LSMeans of decay incidence and time of application of propiconazole after inoculation for the range of times evaluated. Thus, the efficacy of the two rates decreased similarly over time. Decay incidence was 12.4 and $8.7 \%$ at the 12-h timing and increased to 39.4 and $33.0 \%$ at the 24-h timing using the 256- and $384-\mu \mathrm{g} / \mathrm{ml}$ rates, respectively (Fig. 2A). For comparison, an average of $95.0 \%$ of the fruit in the water-treated control developed sour rot. For grapefruit, treatments with propiconazole at 256 $\mu \mathrm{g} / \mathrm{ml} 18 \mathrm{~h}$ after inoculation still resulted in a high efficacy, with $2.2 \%$ decay incidence compared with the untreated control, where $80.9 \%$ of the fruit had sour rot (Fig. 2B). When treatments were delayed 30 or $42 \mathrm{~h}$ after inoculation, the incidence on treated fruit increased to 17.6 or $78.8 \%$, respectively.

In evaluations on the effect of treatment rate on the efficacy of propiconazole against sour rot, the regression models for both inoculum levels tested on lemon as well as for the one inoculum concentration tested on grapefruit were significant $(P<0.05)$ and coefficients of determination of the regression lines were 0.91 to 0.99 . The slopes of the regressions of transformed decay incidence on propiconazole concentration were negative (Fig. 3A and B). In the analyses of covariance, slopes for the regression lines were not significantly different $(P=0.76)$ for the two inoculum concentrations used on lemon and the model estimates indicated a strong linear relationship between LSMeans of decay incidence and concentrations of propiconazole evaluated. The predicted LSMeans from the parallel line regression models evaluated at the mean of the covariate were significantly different $(P<0.001)$. Thus, efficacy of propiconazole using the lower inoculum concentration was significantly higher than for the higher inoculum concentration. Using the lower inoculum concentration, decay was reduced to $6.4 \%$ using propiconazole at $64 \mu \mathrm{g} / \mathrm{ml}$ and to $1.5 \%$ using propiconazole at $256 \mu \mathrm{g} / \mathrm{ml}$ compared with the control, with $85.0 \%$ incidence. Using the higher inoculum concentration, decay incidence ranged from $3.9 \%$ using propiconazole at $516 \mu \mathrm{g} / \mathrm{ml}$ to $37.2 \%$ using propiconazole at $64 \mu \mathrm{g} / \mathrm{ml}$ compared with the control, with $90.4 \%$. For grapefruit, decay incidence also decreased linearly from $56.2 \%$ using propiconazole at $64 \mu \mathrm{g} / \mathrm{ml}$ to $9.7 \%$ using propiconazole at 256 $\mu \mathrm{g} / \mathrm{ml}$ compared with the control, with $67.4 \%$ (Fig. 3B).

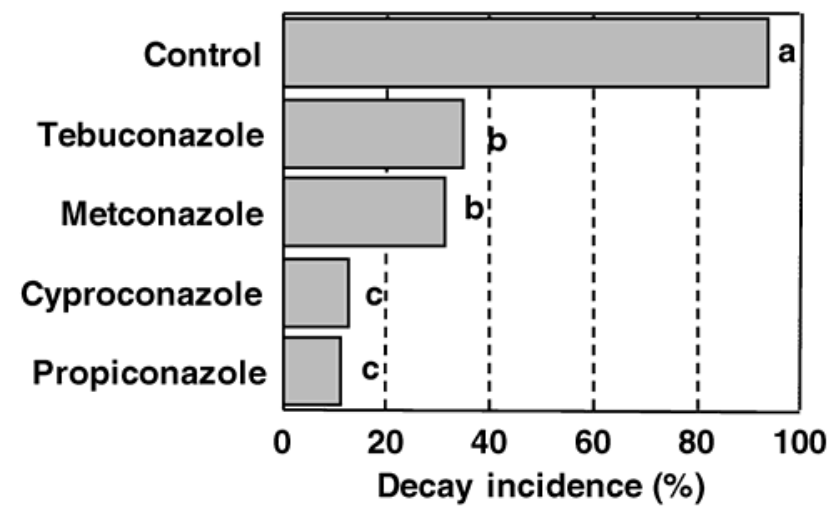

Fig. 1. Effect of selected demethylation-inhibiting triazole fungicides on incidence of postharvest sour rot of lemon fruit. Spray applications to run-off with aqueous fungicide preparations $(256 \mu \mathrm{g} / \mathrm{ml})$ were done $14 \mathrm{~h}$ after wound inoculation with Galactomyces citri-aurantii at $1 \times 10^{7}$ conidia/ml prepared in sterile water and addition of cycloheximide at $2 \mu \mathrm{g} / \mathrm{ml}$. Decay incidence was evaluated after 6 days of incubation at $20^{\circ} \mathrm{C}$. Horizontal bars with the same letter indicate that treatment means were not significantly different $(P<0.05)$ following an analysis of variance and least significant difference means separation procedures.
Effect of sanitizing treatments and SBC on the efficacy of propiconazole in reducing sour rot of lemon. In two laboratory studies using dip applications, sodium hypochlorite did not reduce decay whereas HPPA slightly reduced the incidence of sour rot in wound-inoculated fruit (Figs. 4 and 5). SBC was evaluated at rates that are commonly used commercially and was significantly more effective when used at 3 than at $1 \%$ (Fig. 4). When applied at 3\% $16 \mathrm{~h}$ after inoculation, sour rot was reduced from $97.5 \%$ incidence in the control to $46.2 \%$. The efficacy of propiconazole was not affected when mixed with 1 or $3 \%$ SBC or with sodium hypochlorite at $100 \mu \mathrm{g} / \mathrm{ml}$, although a trend for reduced decay was observed with the mixtures (Fig. 4). When propiconazole was mixed with $3 \%$ SBC plus sodium hypochlorite, the efficacy in reducing sour rot was significantly increased compared with propiconazole alone (Fig. 4) but, when mixed with HPPA, the efficacy was reduced significantly compared with propiconazole alone (Fig. 5).

Laboratory and experimental packing-line studies on the efficacy of propiconazole using different application strategies. In laboratory comparisons of dip and spray applications with propiconazole, the efficacy of propiconazole was numerically but not significantly increased in the dip treatment (Fig. 6). When heated $\left(48^{\circ} \mathrm{C}\right)$ and nonheated propiconazole treatments were compared, the efficacy of the fungicide was not significantly improved by the heated treatment (Fig. 6).

In a comparative experimental packing-line study using propiconazole as aqueous in-line drench applications at $250 \mu \mathrm{g} / \mathrm{ml}$, as
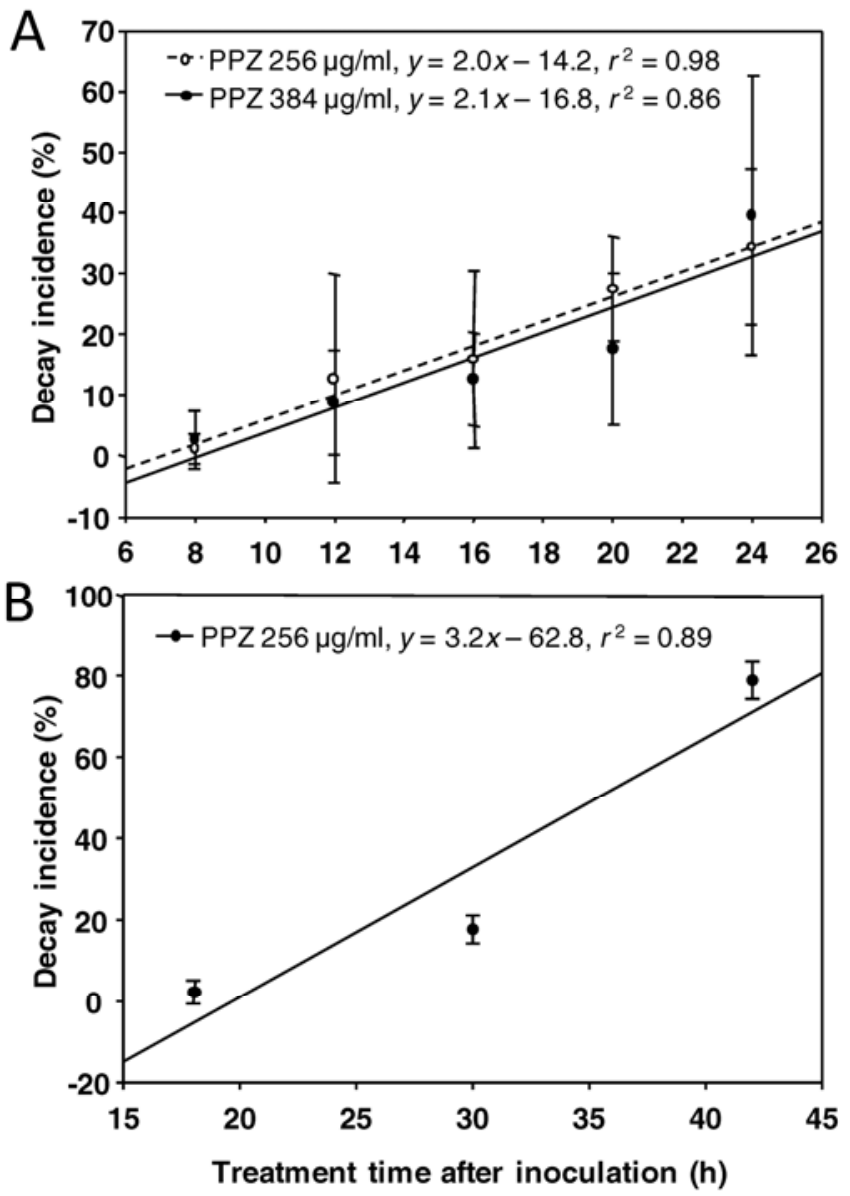

Fig. 2. Effect of treatment time after inoculation on the efficacy of propiconazole in managing sour rot of $\mathbf{A}$, lemon or $\mathbf{B}$, grapefruit in laboratory studies. Fruit were dipped for $15 \mathrm{~s}$ in aqueous propiconazole (PPZ) solutions at $256 \mu \mathrm{g} / \mathrm{ml}$ (closed circles) or $384 \mu \mathrm{g} / \mathrm{ml}$ (open circles; lemon only) at selected times after wound inoculation with conidia of Galactomyces citri-aurantii (5 × $10^{5}$ conidia/ml, prepared in autoclaved lemon juice and cycloheximide at $2 \mu \mathrm{g} / \mathrm{ml}$ added for lemon; $1 \times 10^{7}$ conidia/ml, prepared in lemon juice for grapefruit) and incubation at $20^{\circ} \mathrm{C}$. Decay incidence was regressed on treatment time after inoculation. Vertical bars represent standard errors for each treatment time from two experiments. 
spray applications at $2,000 \mu \mathrm{g} / \mathrm{ml}$ in mixtures with fruit coatings, or as staged treatments where the aqueous drench application was followed by a spray application in a fruit coating at $500 \mu \mathrm{g} / \mathrm{ml}$, significant differences were observed in the effectiveness of the fungicide. The aqueous drench application by itself or in combination with a spray application in storage or packing fruit coating was highly effective, with an incidence of decay of 0 to $1.2 \%$ compared with the control, where $83.8 \%$ of the fruit showed symptoms of sour rot (Table 1). In contrast, single propiconazole spray applications made directly in storage or packing fruit coating were significantly less effective and resulted in 49.1 .0 or $57.1 \%$ decay, respectively.

In-line drench applications with propiconazole at $256 \mu \mathrm{g} / \mathrm{ml}$ applied 12 or $16 \mathrm{~h}$ after inoculation in another experimental packingline study reduced sour rot from an incidence of $52.5 \%$ in the control to 0 or $3.7 \%$, respectively (Table 2). The azoxystrobin-fludioxonil premixture was not effective against sour rot. In this study, we also evaluated the efficacy of these treatments against citrus green mold. When fruit were inoculated with an isolate of $P$. digitatum sensitive against the DMI-imidazole imazalil, propiconazole applications timed 12 and $16 \mathrm{~h}$ after inoculation reduced decay to 6.3 and $9.2 \%$, respectively, compared with the control, with $65.1 \%$ green mold (Table 2). Propiconazole, however, was not effective against green mold caused by an isolate of $P$. digitatum moderately resistant to imazalil. The triple fungicide mixture of propiconazole
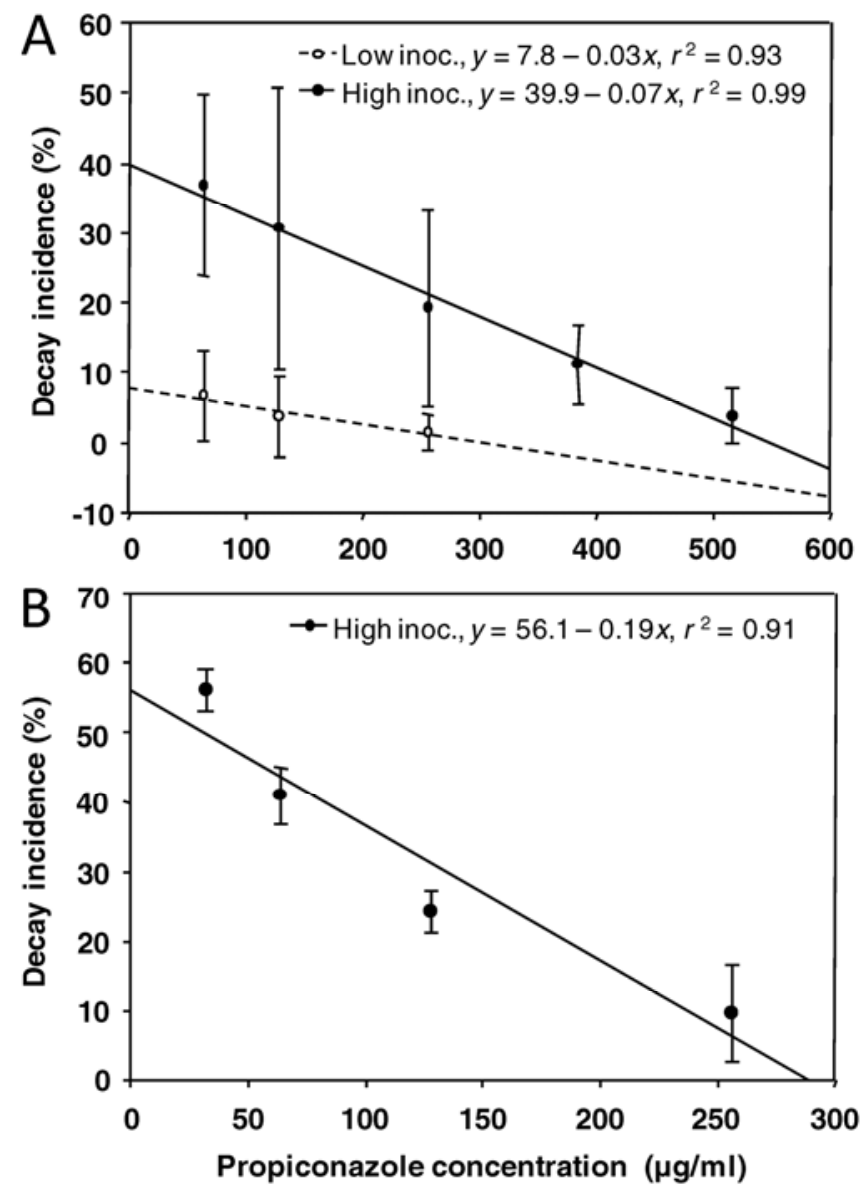

Fig. 3. Effect of treatment rate on the efficacy of propiconazole in managing sour rot of $\mathbf{A}$, lemon or $\mathbf{B}$, grapefruit in laboratory studies. Fruit were dipped for $15 \mathrm{~s}$ in aqueous propiconazole solutions $12 \mathrm{~h}$ (lemon) or $18 \mathrm{~h}$ (grapefruit) after wound inoculation with Galactomyces citri-aurantii at $1 \times 10^{7}$ conidia/ml, a high inoculum concentration prepared in autoclaved lemon juice (closed circles), or at $5 \times 10^{5}$ conidia/ml, a low inoculum concentration prepared in autoclaved lemon juice and with the addition of cycloheximide at $2 \mu \mathrm{g} / \mathrm{ml}$ (open circles; lemon only). Fruit were incubated for 6 days at $20^{\circ} \mathrm{C}$. Decay incidence was regressed on propiconazole concentration. Vertical bars represent standard errors for each treatment time from two experiments.
(256 or $512 \mu \mathrm{g} / \mathrm{ml}$ ), azoxystrobin (300 $\mu \mathrm{g} / \mathrm{ml})$, and fludioxonil (300 $\mu \mathrm{g} / \mathrm{ml}$ ) effectively reduced sour rot and green mold caused by isolates of $P$. digitatum sensitive and moderately resistant to imazalil, and there was no negative interaction between propiconazole and azoxystrobin/fludioxonil (Table 2).

\section{Discussion}

In this study, we provide new evidence that the fungicide propiconazole can be effectively used for the postharvest management

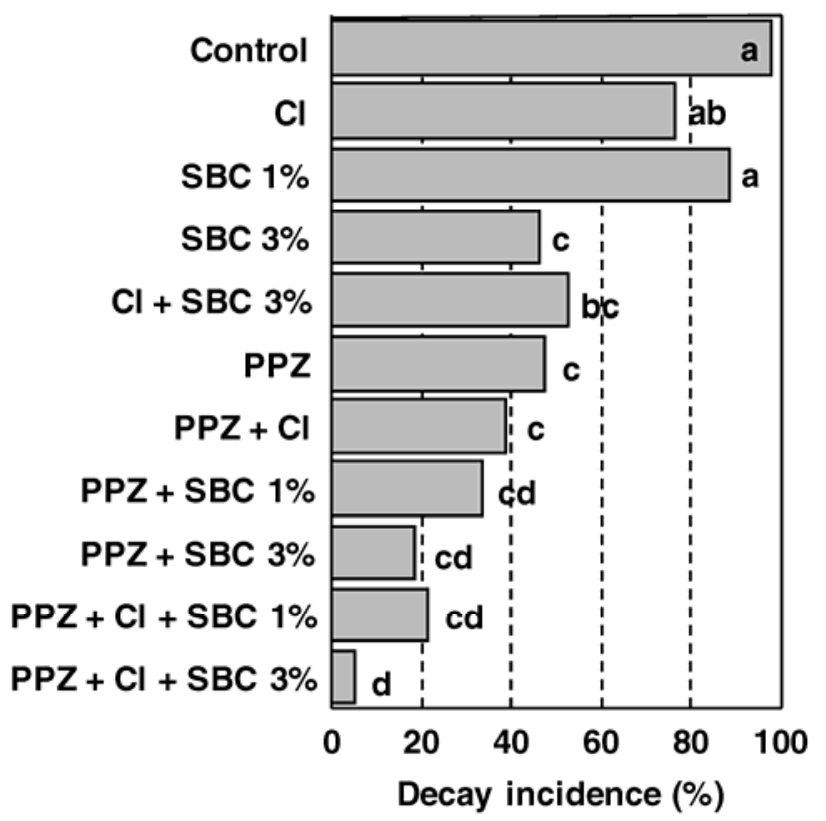

Fig. 4. Effect of sodium hypochlorite and sodium bicarbonate on the efficacy of propiconazole (PPZ) to control sour rot of lemon fruit. Fruit were dip treated for $15 \mathrm{~s}$ $16 \mathrm{~h}$ after wound inoculation with Galactomyces citri-aurantii $\left(1 \times 10^{7}\right.$ conidia/ml, prepared in autoclaved lemon juice). Aqueous treatment solutions of PPZ (384 $\mu \mathrm{g} / \mathrm{ml}$ ) were prepared without or with the addition of sodium hypochlorite ( $\mathrm{Cl}$; free chlorine at $100 \mu \mathrm{g} / \mathrm{ml}$ ) or sodium bicarbonate (SBC; 1 or $3 \%$ [wt/vol]). Fruit were incubated for 6 days at $20^{\circ} \mathrm{C}$. Horizontal bars with the same letter indicate that treatment means were not significantly different $(P<0.05)$ following an analysis of variance and least significant difference means separation test procedures.

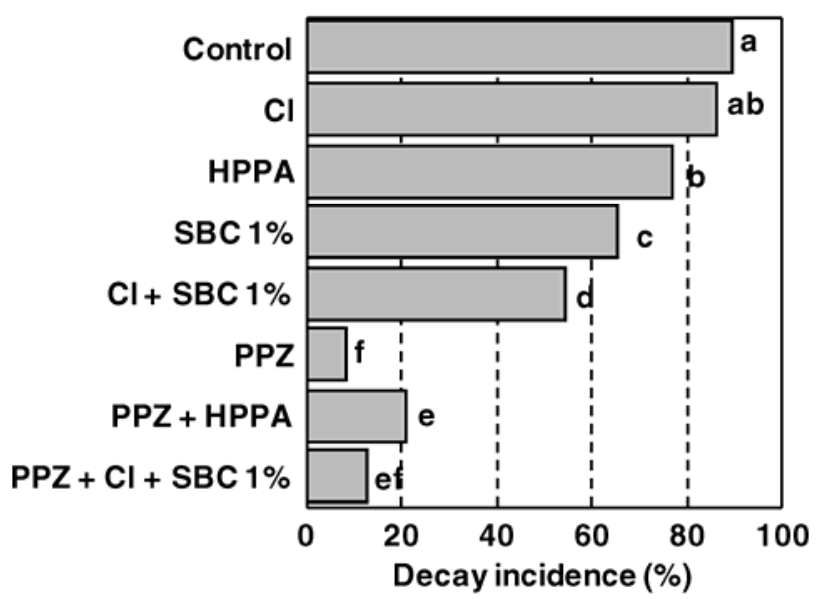

Fig. 5. Effect of sanitizing agents and sodium bicarbonate on the efficacy of propiconazole (PPZ) to control sour rot of lemon fruit. Fruit were dip treated for $15 \mathrm{~s} 14 \mathrm{~h}$ after wound inoculation with Galactomyces citri-aurantii $\left(1 \times 10^{7}\right.$ conidia/ml, prepared in autoclaved lemon juice). Aqueous treatment solutions of PPZ (256 $\mu \mathrm{g} / \mathrm{ml})$ were prepared without or with the addition of sodium hypochlorite $(\mathrm{Cl}$; free chlorine at $100 \mu \mathrm{g} / \mathrm{ml}$ ), hydrogen peroxide (HPPA; $80 \mu \mathrm{g} / \mathrm{ml}$, using a hydrogen peroxideperoxyacetic acid mixture), or sodium bicarbonate (SBC; $1 \%$ [wt/vol]). Fruit were incubated for 6 days at $20^{\circ} \mathrm{C}$. Horizontal bars with the same letter indicate that treatment means were not significantly different $(P<0.05)$ following an analysis of variance and least significant difference means separation test procedures. 
of sour rot of citrus caused by G. citri-aurantii and we present information that will help to design use strategies to obtain maximum decay control. The efficacy of DMI fungicides against sour rot was demonstrated previously by others. For example, the triazole etaconazole reduced the incidence of sour rot of orange by $53.4 \%$ (8). The morpholine fenpropimorph and the triazole flutriafol showed comparable reductions in disease incidence of inoculated orange fruit in another study (11). These fungicides, however, were never registered in the United States on citrus or for postharvest use. In our own comparative evaluations, propiconazole and cyproconazole were similarly effective and more effective than metconazole and tebuconazole at equivalent rates. These DMI compounds were chosen because they were the most effective in laboratory sensitivity studies with $G$. citri-aurantii and $G$. geotrichum among members of that fungicide group evaluated $(24,25)$. Propiconazole has been available for preharvest use on a variety of crops for numerous years and is planned for registration on stone fruit and other crops for the postharvest management of sour rot caused by G. geotrichum and of other decays. The fungicide was found previously to be effective against citrus sour rot (18) but registration was not pursued at this time. With the new interest in this compound as a postharvest treatment, favorable toxicological characteristics for agricultural food crop registration, and support by the registrant, propiconazole will be the first highly effective treatment for the management of sour rot of citrus and other crops in the United States.

Our evaluations were done using inoculated lemon and grapefruit. The incidence of decay in the nontreated control varied widely among experiments and sometimes was too low to obtain

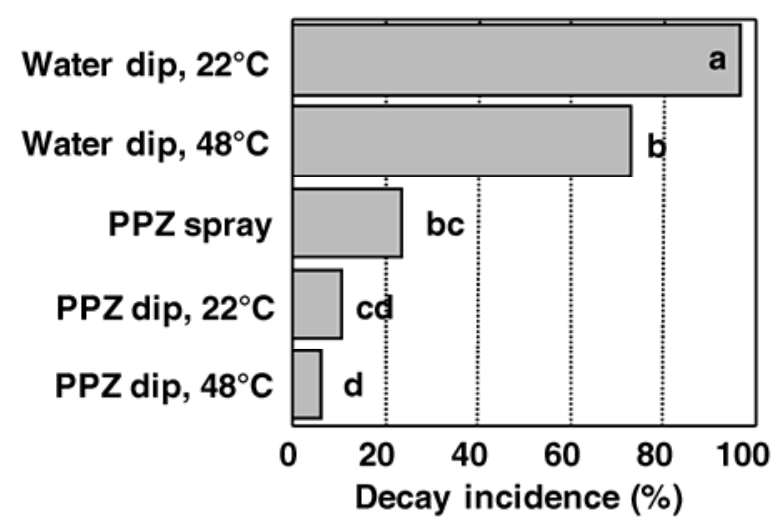

Fig. 6. Efficacy of propiconazole (PPZ) for control of sour rot of lemon fruit using applications at two temperatures. Fruit were dip treated for $15 \mathrm{~s}$ or spray treated to run-off $14 \mathrm{~h}$ after wound inoculation with Galactomyces citri-aurantii $\left(1 \times 10^{7}\right.$ conidia/ml, prepared in autoclaved lemon juice). Aqueous dip treatments were done either at ambient temperature $\left(22^{\circ} \mathrm{C}\right)$ or heated $\left(48^{\circ} \mathrm{C}\right)$, whereas sprays were done only at ambient temperature. PPZ was applied at $256 \mu \mathrm{g} / \mathrm{ml}$. After treatment, fruit were incubated for 6 days at $20^{\circ} \mathrm{C}$. Horizontal bars with the same letter indicate that treatment means were not significantly different $(P<0.05)$ following an analysis of variance and least significant difference means separation test procedures. meaningful data. The difficulty of obtaining consistent sour rot decay of inoculated fruit was recognized previously by others and this was associated initially with fruit maturity and water content of the rind $(4,5)$. The exact mechanism involved in fruit susceptibility, however, has not been elucidated (14). To increase consistency in inoculations for sour rot, some researchers have tried to predispose citrus fruit by submerging it in water (12). Others have added various chemicals to the inoculum. Cycloheximide, blasticidin $\mathrm{S}$, glyphosate, and pectinase were found to be most effective in increasing the incidence of decay (15). In still other studies, higher conidial concentrations were used that led to an increased activity of polygalacturonase (26), a macerate of decayed lemon peel was added to the inoculum suspension (11), or inoculum was prepared in fresh lemon juice (31). In our inoculations, decay was most consistently obtained when inoculum was prepared in autoclaved lemon juice and when either a low conidial concentration (i.e., $5 \times 10^{5}$ conidial $/ \mathrm{ml}$ ) was used together with cycloheximide at $2 \mu \mathrm{g} / \mathrm{ml}$ or a high conidial concentration (i.e., $1 \times 10^{7}$ conidial $/ \mathrm{ml}$ ) without any additive was used. For most studies presented here, inoculum was prepared using both of these methods and data are presented for those experiments where decay incidence in the untreated control was at least $50 \%$.

Our experiments identified critical application timings and rates for propiconazole treatments of inoculated fruit. For lemon, using two treatment rates $(256$ and $512 \mu \mathrm{g} / \mathrm{ml}$ ), decay incidence increased rapidly when treatments were delayed for more than $12 \mathrm{~h}$ after inoculation. In studies by others with fenpropimorph, no decay developed when treatments were done within $6 \mathrm{~h}$ of inoculation but incidence was $92 \%$ when applied after $24 \mathrm{~h}$ (11). Based on our results, commercial treatments with propiconazole to lemon fruit should not be delayed for more than $16 \mathrm{~h}$ after harvest to obtain good control. In contrast, for grapefruit, treatments done $18 \mathrm{~h}$ after inoculation still provided a very high efficacy. Reduced performance due to delayed application of postharvest fungicides is largely due to (i) the rate of development of the fungus in the host tissue or (ii) the lack of apoplastic and symplastic mobility (systemic activity) of the fungicide in the host tissues (21). It is unclear whether the differences we observed between the two citrus species can be generalized. Grapefruit are considered very susceptible to sour rot. Possibly, the Oroblanco cultivar used in our studies is more resistant to sour rot and the pathogen advances more slowly into the tissue. Alternatively, the fungicide may have penetrated deeper into the rind tissue of grapefruit than of lemon.

Propiconazole concentrations were used as suggested by the registrant. A concentration of $256 \mu \mathrm{g} / \mathrm{ml}$ was sufficient to reduce decay to very low levels on lemon fruit inoculated with a low conidial concentration and for grapefruit inoculated with a high concentration. For lemon fruit using the high inoculum concentration, a rate of $512 \mu \mathrm{g} / \mathrm{ml}$ was required to achieve a similar high level of sour rot control. This suggests that commercial applications to fruit that are not being stored could be done at a lower rate because infections occurring in the field mainly originate from inoculum adhering to soil particles where conidial concentrations can be considered low. However, in long-term storage, a common

Table 1. Efficacy of propiconazole for control sour rot of lemon fruit in an experimental packing-line study ${ }^{\mathrm{y}}$

\begin{tabular}{|c|c|c|c|c|c|c|c|c|c|}
\hline \multirow[b]{2}{*}{ Number } & \multicolumn{4}{|c|}{ First application } & \multicolumn{4}{|c|}{ Second application } & \multirow[b]{2}{*}{ Incidence $(\%)^{\mathrm{z}}$} \\
\hline & Treatment & Rate $(\mu \mathrm{g} / \mathrm{ml})$ & Method & Coating & Treatment & Rate $(\mu \mathrm{g} / \mathrm{ml})$ & Method & Coating & \\
\hline 1 & Water & & Drench & None & $\ldots$ & $\ldots$ & $\ldots$ & Storage & $83.8 \mathrm{a}$ \\
\hline 2 & PPZ & 2,000 & LV-spray & Storage & $\ldots$ & $\ldots$ & $\ldots$ & $\ldots$ & $49.1 \mathrm{~b}$ \\
\hline 3 & PPZ & 2,000 & LV-spray & Packing & $\ldots$ & $\ldots$ & $\ldots$ & $\ldots$ & $57.1 \mathrm{~b}$ \\
\hline 4 & PPZ & 250 & Drench & None & $\ldots$ & $\ldots$ & $\ldots$ & $\ldots$ & $0.0 \mathrm{c}$ \\
\hline 5 & PPZ & 250 & Drench & None & PPZ & 500 & LV-spray & Storage & $0.6 \mathrm{c}$ \\
\hline 6 & PPZ & 250 & Drench & None & PPZ & 500 & LV-spray & Packing & $1.2 \mathrm{c}$ \\
\hline
\end{tabular}

y Treatments were applied 14 to $16 \mathrm{~h}$ after inoculation with Galactomyces citri-aurantii $\left(1 \times 10^{7}\right.$ conidia/ml, prepared in autoclaved lemon juice). Propiconazole (PPZ) was applied as a high-volume, in-line drench application or as a low-volume (LV), in-line spray on a roller bed in either an aqueous or fruit coating preparation (see Materials and Methods). After treatment, fruit were incubated for 6 days at $20^{\circ} \mathrm{C}$.

${ }^{\mathrm{z}}$ Sour rot incidence. Values with the same letters indicate that treatment means were not significantly different $(P<0.05)$ following an analysis of variance and least significant difference means separation test procedures. 
practice for lemon in California, infections are mainly initiated from juices dripping from infected fruit, where conidial concentrations can be very high. Thus, for fruit being stored, a higher rate of propiconazole will be beneficial. In our postharvest studies using different application strategies, fruit were treated with propiconazole at $256 \mu \mathrm{g} / \mathrm{ml}$ up to $16 \mathrm{~h}$ after inoculation. This extended postinoculation interval was used to discern fungicide-treatment interactions more clearly.

Numerous studies have demonstrated the effective management of postharvest pathogens of citrus using drench or soak treatments with alkaline solutions of carbonate, bicarbonate, or sorbate salts $(20,23,27,31,32)$, and these treatments have been in commercial use for over 50 years (2). A standard practice in California packinghouses is to drench fruit over rotating brushes or soak fruit in a tank using a heated $\left(46\right.$ to $52^{\circ} \mathrm{C}$ ) recirculating solution of 1 to $3 \%$ sodium bicarbonate, sometimes with sodium hypochlorite (chlorine) at 100 to $200 \mu \mathrm{g} / \mathrm{ml}$ added, and then rinse fruit with water. Used alone, however, these treatments have limitations for postharvest decay control. Thus, other fungicides are sometimes added to the solution or are applied subsequently. We found that SBC applied at $3 \%$ by itself or in combination with chlorine at ambient temperature significantly reduced the incidence of sour rot of inoculated fruit. When combined with propiconazole, a slight additive effect of the SBC or SBC-chlorine and propiconazole treatments was observed. SBC used at $1 \%$, a concentration that is often preferred in commercial use to avoid dehydration of fruit (20), reduced sour rot compared with the control in only one of the two studies. Still, no negative interaction with propiconazole was observed.

The increased efficacy of some citrus postharvest fungicides against green mold when applied at higher temperature $(13,29,31)$ led to the common practice of using heated fungicide solutions. Heated dip treatments with propiconazole in our study did not improve the efficacy against sour rot compared with nonheated solutions. Application times of $15 \mathrm{~s}$ may not have been long enough for treating fruit at 20 to $25^{\circ} \mathrm{C}$ and, possibly, longer timings could improve efficacy. In commercial soak applications in tanks with SBC or fungicides, fruit generally remain submerged for 2 to 4 min.

HPPA at $2,700 \mu \mathrm{g} / \mathrm{ml}$ was previously shown to have no negative interactions with thiabendazole, imazalil, pyrimethanil, and fludioxonil (23). In our study with propiconazole using HPPA at 80 $\mu \mathrm{g} / \mathrm{ml}$, efficacy of propiconazole was slightly reduced. A lower concentration of HPPA was used in the current study because fruit treated with HPPA at $80 \mu \mathrm{g} / \mathrm{ml}$ do not require a water rinse and, thus, HPPA can be directly incorporated into the fungicide solution. HPPA at $80 \mu \mathrm{g} / \mathrm{ml}$ has been successfully used for surface sanitation of cherry and peach fruit in California (J. E. Adaskaveg, unpublished).

Experimental packing-line studies were conducted to evaluate the performance of propiconazole under conditions similar to commercial packinghouse practices and to evaluate additional applica- tion strategies. An important component of postharvest applications is the use of fruit coatings. Fruit that are marketed soon after harvest (most orange, grapefruit, and mandarin) are commonly treated with a fungicide and a packing fruit coating. Lemon fruit and some other citrus fruit in California, however, are often stored for several months before marketing. Before storage, they are treated with a fungicide and a storage fruit coating. Before marketing, a second fungicide application in combination with a packing fruit coating is done (20). Although fungicides can be directly mixed with fruit coatings, the efficacy in reducing decay is often decreased compared with an aqueous application (23), and this was also observed in our studies with propiconazole. This reduced efficacy has been attributed to a reduced movement of the fungicide and limited penetration into the fruit rind and into sites with developing infections $(19,23)$. Because of the higher efficacy in aqueous solutions and the need for using a fruit coating, staged fungicide applications have become a common practice. In these applications, an aqueous fungicide treatment is followed by an application with fruit coating that may also contain a fungicide. Using this strategy in our experimental packing-line study, sour rot was reduced to very low levels, similar to an aqueous treatment alone. The two-stage application with incorporation of a fungicide in the fruit coating can have a specific advantage for managing Penicillium decays where control of sporulation on decaying fruit is another important goal of postharvest treatments. The antisporulation activity of some compounds such as fludioxonil and azoxystrobin may be increased when applied in a fruit coating (22) but decay control may then be compromised. Thus, the two-stage application maximizes decay as well as sporulation control of some decay organisms (e.g., Penicillium spp.).

Several fungicides are currently registered in the United States to manage Penicillium decays of citrus fruit. The recent registration of azoxystrobin, fludioxonil, and pyrimethanil introduced new classes of fungicides with new modes of action that allow the effective control of decay caused by widespread populations of Penicillium spp. that are resistant against the older fungicides thiabendazole and imazalil. The current trend to minimize the development of resistance includes the use of fungicide mixtures and premixtures where at least two components are effective against a specific pathogen. Isolates of Penicillium spp. resistant to imazalil are cross-resistant to propiconazole (25). As we demonstrated in the current study, decay caused by imazalil-resistant isolates of $P$. digitatum cannot be managed with propiconazole and, thus, fungicides with different modes of action have to be used. Propiconazole, however, could be used for early-season fruit when the incidence of DMI resistance in packinghouses is generally low (J. E. Adaskaveg, unpublished). With only propiconazole available for effective sour rot control, ideally a triple-fungicide mixture could be applied, with two components active against Penicillium spp. and with propiconazole as the sour rot fungicide. As we demonstrated, the azoxystrobin-fludioxonil-propiconazole mixture was highly effective against sour rot as well as green mold caused

Table 2. Efficacy of aqueous in-line fungicide drenches against green mold and sour rot of lemon fruit

\begin{tabular}{|c|c|c|c|c|}
\hline \multirow[b]{2}{*}{ Treatment and rate } & \multirow[b]{2}{*}{ Time $(h)^{z}$} & \multicolumn{3}{|c|}{ Decay incidence $(\%)^{x}$} \\
\hline & & Sour rot & Green mold, S & Green mold, MR \\
\hline Control & 12 & $52.5 \mathrm{a}$ & $65.1 \mathrm{a}$ & $83.3 \mathrm{a}$ \\
\hline PPZ $256 \mu \mathrm{g} / \mathrm{ml}$ & 12 & $0 \mathrm{~b}$ & $6.3 \mathrm{~b}$ & $73.8 \mathrm{a}$ \\
\hline PPZ $256 \mu \mathrm{g} / \mathrm{ml}$ & 16 & $3.7 \mathrm{~b}$ & $9.2 \mathrm{~b}$ & NT \\
\hline Fludioxonil $300 \mu \mathrm{g} / \mathrm{ml}+$ azoxystrobin $300 \mu \mathrm{g} / \mathrm{ml}$ & 12 & $37.7 \mathrm{a}$ & $2.7 \mathrm{bc}$ & NT \\
\hline Fludioxonil $300 \mu \mathrm{g} / \mathrm{ml}+$ azoxystrobin $300 \mu \mathrm{g} / \mathrm{ml}+$ PPZ $256 \mu \mathrm{g} / \mathrm{ml}$ & 12 & $2.8 \mathrm{~b}$ & NT & $1.2 \mathrm{~b}$ \\
\hline Fludioxonil $300 \mu \mathrm{g} / \mathrm{ml}+$ azoxystrobin $300 \mu \mathrm{g} / \mathrm{ml}+$ PPZ $512 \mu \mathrm{g} / \mathrm{ml}$ & 12 & $0 \mathrm{~b}$ & $0 \mathrm{c}$ & $1.2 \mathrm{~b}$ \\
\hline
\end{tabular}

${ }^{\mathrm{x}}$ Fruit were inoculated with isolates of the green mold pathogen Penicillium digitatum $\left(1 \times 10^{6}\right.$ conidia/ml) sensitive $\left(\mathrm{S} ; 50 \%\right.$ effective concentration [EC $\left.{ }_{50}\right]$ $=0.05 \mu \mathrm{g} / \mathrm{ml})$ or moderately resistant $\left(\mathrm{MR} ; \mathrm{EC}_{50}=0.32 \mu \mathrm{g} / \mathrm{ml}\right)$ to imazalil or with the sour rot pathogen Galactomyces citri-aurantii $\left(5 \times 10^{5}\right.$ conidia/ml, in autoclaved lemon juice plus cycloheximide at $2 \mu \mathrm{g} / \mathrm{ml}$ ); $\mathrm{NT}=$ not tested. Mean values of decay incidence in each column followed by the same letter are not statistically different $(P<0.001)$ according to analysis of variance and least significant difference mean separation procedures.

${ }^{y}$ Aqueous fungicide treatments were followed by a low-volume spray with diluted storage fruit coating. Fludioxonil and azoxystrobin were applied as the commercial premixture Graduate A+. PPZ = propiconazole.

z Time after inoculation. 
by imazalil-sensitive and -resistant isolates of $P$. digitatum. With reduced usage of SOPP fungicides and the need for a sour rot control material other than the carbonate salts that can desiccate fruit and reduce storage time, propiconazole will be an excellent fungicide for the integrated postharvest management of citrus sour rot and of decays caused by DMI-sensitive isolates of Penicillium spp.

\section{Acknowledgments}

We thank D. Felts, J. Enns, and L. Hou for technical assistance and the California Citrus Research Board for financial support of this research.

\section{Literature Cited}

1. Adaskaveg, J. E., Förster, H., Driever, G., and Crisosto, C. 2007. Update on Mentor 45WP-a "new tool" for postharvest management of sour rot of stone fruit in the 2007 season. Pages 1-4. Online publication. http://www2. uckac.edu/postharv/new-CVPN.htm.

2. Adaskaveg, J. E., Förster, H., and Sommer, N. F. 2002. Principles of postharvest pathology and management of decays of edible horticultural crops. Pages 163-195 in: Postharvest Technology of Horticultural Crops. A. A. Kader, ed. Univ. Calif. Agric. Nat. Resour. Publ. No. 3311, Oakland.

3. Anonymous. 2011. California Department of Food and Agriculture. Page 69. Online publication. http://www.cdfa.ca.gov/statistics/PDFs/AgResource Directory_2010-2011/4FruitGrape10_WEB.pdf.

4. Baudoin, A. B. A. M., and Eckert, J. W. 1982. Factors influencing the susceptibility of lemons to infection by Geotrichum candidum. Phytopathology 72:1592-1597

5. Baudoin, A. B. A. M., and Eckert, J. W. 1985. Development of resistance against Geotrichum candidum in lemon peel injuries. Phytopathology 75:174-179.

6. Block, S. S. 2001. Peroxygen compounds. Pages 185-204 in: Disinfection, Sterilization and Preservation, 5th ed. S. S. Block, ed. Lippincott Williams and Wilkins, Philadelphia.

7. Brown, G. E. 1979. Biology and control of Geotrichum candidum the cause of citrus sour rot. Proc. Fla. State Hortic. Soc. 92:186-189.

8. Brown, G. E. 1986. Effectiveness of postharvest fungicides for the control of citrus fruit decays. Proc. Fla. State Hortic. Soc. 98:208-211.

9. Butler, E. E., Webster, R. K., and Eckert, J. W. 1965. Taxonomy, pathogenicity, and physiological properties of the fungus causing sour rot of citrus. Phytopathology 55:1262-1268

10. Cochran, A., Adaskaveg, J. E., and Förster, H. 2009. Propiconazole and fludioxonil for managing postharvest fungal decays of fresh market tomato. (Abstr.) Phytopathology 99:S23.

11. Cohen, E. 1989. Evaluation of fenpropimorph and flutriafol for control of sour rot, blue mold, and green mold in lemon fruit. Plant Dis. 73:807-809.

12. Cohen, E., Coggins, C. W., Jr., and Eckert J. W. 1991. Predisposition of citrus fruits to sour rot when submerged in water. Plant Dis. 75:166-168.

13. D'Aquino, S., Schirra, M., Palma, A., Angioni, A., Cabras, P., and Migheli, Q. 2006. Residue level and effectiveness of pyrimethanil vs. imazalil when using heated postharvest treatments for control of Penicillium decay on citrus fruit. J. Agric. Food Chem. 54:4721-4726.

14. Davis, L. L., and Baudoin, A. B. A. M. 1986. Effect of osmotic potential on Geotrichum candidum growth, polygalacturonase production and polygalacturonase action. Physiol. Mol. Plant Pathol. 28:53-60.

15. deMatos, A. P., and Eckert, J. W. 1983. Inoculum additives to increase the susceptibility of lemons to Geotrichum candidum. (Abstr.) Phytopathology 73:958.

16. Domsch, K. H., Gams, W., and Anderson, T.-H. 1993. Compendium of Soil Fungi, Volume 1. IHW-Verlag, Eching, Germany.

17. Eckert, J. W. 1959. Lemon sour rot. Calif. Citrogr. 45:30-36.

18. Eckert, J. W., Bretschneider, B. F, and Ratnayake, M. 1981. Investigations on new postharvest fungicides for citrus fruits in California. Proc. Int. Soc.
Citric. 2:804-810.

19. Eckert, J. W., and Brown, G. E. 1986. Evaluation of postharvest treatments for citrus fruits. Pages 92-97 in: Methods for Evaluating Pesticides for Control of Plant Pathogens. K. D. Hickey, ed. American Phytopathological Society, St. Paul, MN.

20. Eckert, J. W., and Eaks, I. L. 1989. Postharvest disorders and diseases of citrus fruits. Pages 180-260 in: The Citrus Industry: Volume V. W. Reuther, C. E. Calavan, and G. E. Carmen, eds. University of California, Division of Agriculture and Natural Resources, Oakland.

21. Hewitt, H. G. 1998. Fungicides in Crop Protection. CAB International, Cambridge, UK.

22. Kanetis, L., Förster, H., and Adaskaveg, J. E. 2007. Comparative efficacy of the new postharvest fungicides azoxystrobin, fludioxonil, and pyrimethanil for managing citrus green mold. Plant Dis. 91:1502-1511.

23. Kanetis, L., Förster, H., and Adaskaveg, J. E. 2008. Optimizing efficacy of new postharvest fungicides and evaluation of sanitizing agents for managing citrus green mold. Plant Dis. 92:261-269.

24. McKay, A. H., Förster, H., and Adaskaveg, J. E. 2007. Sensitivity of isolates of Geotrichum citri-aurantii, the causal pathogen of sour rot in citrus, to DMI fungicides. (Abstr.) Phytopathology 97:S74.

25. McKay, A. H., Förster, H., and Adaskaveg, J. E. Toxicity of selected fungicides to the postharvest pathogens Galactomyces citri-aurantii, $G$ geotrichum, and Penicillium digitatum and resistance potential to propiconazole. Plant Dis. In press.

26. Nakamura, M., Suprapta, D. N., Iwai, H., and Arai, K. 2001. Comparison of endo-polygalacturonase activities of citrus and non-citrus races of Geotrichum candidum, and cloning and expression of the corresponding genes. Mol. Plant Pathol. 2:265-274

27. Palou, L., Smilanick, J. L., Usall, J., and Viñas, I. 2001. Control of postharvest blue and green molds of oranges by hot water, sodium carbonate, and sodium bicarbonate. Plant Dis. 85:371-376.

28. Rippon, L. E., and Morris, S. C. 1981. Guazatine control of sour rot in lemons, oranges and tangors under various storage conditions. Sci. Hortic. 14:245-251.

29. Schirra, M., D'Aquino, S., Palma, A., Marceddu, S., Angioni, A., Cabras, P., Scherm, B., and Migheli. Q. 2005. Residue level, persistence, and storage performance of citrus fruit treated with fludioxonil. J. Agric. Food Chem. 53:6718-6724.

30. Smilanick, J. L., Mansour, M. F., Margosan, D. A., Mlikota Gabler, F., and Goodwine, W. R. 2005. Influence of $\mathrm{pH}$ and $\mathrm{NaHCO}_{3}$ on effectiveness of imazalil to inhibit germination of Penicillium digitatum and to control postharvest green mold on citrus fruit. Plant Dis. 89:640-648.

31. Smilanick, J. L., Mansour, M. F., Mlikota Gabler, F., and Sorenson, D. 2008. Control of citrus postharvest green mold and sour rot by potassium sorbate combined with heat and fungicides. Postharvest Biol. Technol. 47:226-238.

32. Smilanick, J. L., Margosan, D. A., Mlikota Gabler, F., Usall, J., and Michael, I. F. 1999. Control of citrus green mold by carbonate and bicarbonate salts and the influence of commercial postharvest practices on their efficacy. Plant Dis. 83:139-145.

33. Smilanick, J. L., Michael, I. F., Mansour, M. F., Mackey, B. E., Margosan, D. A., Florers, D., and Weist, C. F. 1997. Improved control of green mold of citrus with imazalil in warm water compared with its use in wax. Plant Dis. 81:1299-1304.

34. Smilanick, J. L., and Sorenson, D. 2001. Control of postharvest decay of citrus fruit with calcium polysulfide. Postharvest Biol. Technol. 21:157-168.

35. Suprapta, D. N., Arai, K., Iwai, H., and Matsuo, T. 1996. Change in susceptibility of satsuma mandarin fruit to sour rot pathogen (Geotrichum candidum citrus race) with relation to biochemical changes during maturation and storage. Mycoscience 37:209-216.

36. Wild, B. L. 1992. Variations in sensitivity of isolates of Geotrichum candidum to the fungicide guazatine. Australas. Plant Pathol. 21:13-15. 